\title{
Biokonversi Limbah Organik Menjadi Magot Sebagai Sumber Protein Pengganti Tepung Ikan
}

\author{
Bioconversion of Organic Waste into Magot as a Source of Protein to \\ Substitute Fish Meal
}

\author{
Nefi Andriana Fajri* dan Ria Harmayani \\ Fakultas Peternakan, Universitas Nahdlatul Wathan Mataram, \\ Jl. Kaktus No. 1-3 (0370) 641275 Mataram \\ *corresponding author, email: Nefiandriana02@gmail.com
}

Manuscript received: 25-10-2020. Accepted: 20-12-2020

\begin{abstract}
ABSTRAK
Biokonversi merupakan salah satu cara untuk melakukan pengolahan limbah organik (limpah pasar) yang menjadi permasalahan saat ini, yaitu dengan memanfaatkan mikroorganisme seperti larva Black Soldier Fly (BSF) sebagai agen biodegradasi. Penelitian ini bertujuan mempelajari siklus hidup BSF pada media limbah pasar serta mengetahui potensi Larva BSF mengurai limbah pasar. Penelitian ini dilakukan selama 8 bulan mulai dari pra penelitian hingga terlaksananya penelitian. Tahap pengamatan yang dilakukan dalam penelitian ini meliputi 1) siklus hidup BSF pada media limbah organik pasar yang dicacah dan tidak dicacah. 2) potensi larva/maggot BSF dalam mengurai limbah organik pasar yang dicacah dan tidak dicacah. Hasil penelitian menunjukkan bahwa Proses penetasan dari telur menjadi larva dalam waktu tiga sampai empat hari. Fase larva yang masih berwarna putih kekuningan berlangsung kurang lebih 12 hari, pada fase ini larva akan sangat membutuhkan banyak makan. Pada Fase prepupa terjadi sejak hari ke-19 dan fase pupa 100\% dicapai pada hari ke-24-26. Maggot memiliki kemampuan mendegradasi limbah pasar hingga $84 \pm 4.90 \%$ pada limbah pasar yang dilakukan pencacahan dan sekitar $69 \pm 5.83 \%$ mengurai limbah pasar yang tidak dicacah.
\end{abstract}

Kata kunci: larva; limbah; mikroorganisme; pasar; Black Soldier Fly (BSF)

\begin{abstract}
Bioconversion is one of the ways to treat organic waste (market abundance) which is a problem today, namely by utilizing microorganisms such as Black Soldier Fly (BSF) larvae as biodegradation agents. This study aims to study the life cycle of BSF in market waste media and to determine the potential of BSF larvae to break down market waste. This research was conducted for 8 months starting from the pre-study until the implementation of the study. The observation phases carried out in this study included 1) the life cycle of BSF in the chopped and non-chopped organic market waste media. 2) the potential of BSF larva / maggot in breaking down chopped and not chopped organic market waste. The results showed that the hatching process from eggs to larvae took three to four days. The larval phase which is still yellowish white lasts approximately 12 days, in this phase the larvae will need a lot of food. The prepupa phase occurs from the 19th day and the pupal phase is $100 \%$ achieved on the 24-
\end{abstract}


26th day. Maggot has the ability to degrade market waste up to $84 \pm 4.90 \%$ in market waste that is enumerated and around $69 \pm 5.83 \%$ breaks down market waste that is not chopped.

Key words: Black Soldier Fly (BSF); larva; market; microorganisms; waste media

\section{PENDAHULUAN}

Sampah dapat dikelompokkan menjadi dua kelompok, yaitu sampah organik dan sampah anorganik. Sampah organic ditempat kami merupakan sumbangan terbesar dalam penumpukan sampah, contohnya adalah sampah dedaunan, sisa-sisa makanan, kotoran binatang dan lain-lain. Sampah organic mempunyai potensi yang besar untuk dimanfaatkan kembali menjadi barang yang berguna dan bisa mempunyai nilai ekonomi yang cukupbesar. Sebenarnya di Pedesaan, sampah organic banyak dimanfaatkan oleh penduduk. Contoh Kecil Saja dengan mereka membuang sampah organik di lahan perkebunan atau pertanian bias dijadikan sebagai pupuk alami. Namun umumnya kebanyakan dari masyarakat belum mengetahui kalua mengolah sampah organik secara efektif dan kontinu bias meningkatkan penghasilan dari masyarakat. Oleh karena itu perlu adanya upaya pengelolahan yang profesional agar sampah organik bisa menjadi sesuatu yang menghasilkan sesuatu yang berguna dan mempunyai nilai ekonomis.

Dengan memanfaatkan Teknologi Biokonversi dengan menggunakan Larva Lalat Tentara Hitam (BSF), Karena dalam Lalat BSF memiliki aktivitas selulotik dengan adanya bakteri pada ususnya (Supriatna \& Ukit, 2016). Keberadaan bakteri dalam usus larva tersebut membantu larva dalam mengkonversi limbah organic dalam ususnya. Larva BSF mampu mengkonversi limbah organik (Buah-Buahan dan Sayur-Sayuran) menjadi lemak dan protein dalam biomassa tubuhnya (Larde, 1990 ; Shepard \& Newton, 1994; Leclercq, 1997; Oliver, 2001; Newton et al., 2005; Li et al., 2011; Diener et al., 2011; Zheng et al., 2011.

Dari berbagai insekta yang dapat dikembangkan sebagai pakan, kandungan protein larva BSF cukup tinggi, yaitu 40-50\% dengan kandungan lemak berkisar 29-32\% (Bosch et al. 2014). Rambet et al. (2016) menyimpulkan bahwa tepung BSF berpotensi sebagai penggant itepung ikan hingga 100\% untuk campuran pakan ayam pedaging tanpa adanya efek negative terhadap kecernaan bahan kering (57,96-60,42\%), energi $(62,03-64,77 \%)$ dan protein $(64,59-$ $75,32 \%$ ), walaupun hasil yang terbaik diperoleh dari penggantian tepung ikan hingga $25 \%$ atau $11,25 \%$ dalam pakan.

Penyediaan pakan ternak yang berkualitas merupakan salah satu factor penentu keberhasilan industry peternakan dan menjadi komponen terbesar dalam kegiatan usaha tersebut, yaitu 50-70\% (Katayane et al. 2014). Beski et al. (2015) menyatakan bahwa komponen protein mempunyai peran yang penting dalam suatu formula pakan ternak karena terlibat dalam pembentukan jaringan tubuh dan terlibat aktif dalam metabolisme vital seperti enzim, hormon, antibodi dan lain sebagainya.

Tingginya nutrisi yang terkandung pada maggot, ketersediaannya yang melimpah, pemanfaatannya yang tidak bersaing dengan manusia serta media tumbuhnya yang mudah dibuat menunjukkan potensi yang baik sebagai alternative kombinasi pakan ikan. Maggot diharapkan dapat menjadi jawaban atas permasalahan ketersediaan yaitu harga pakan yang 
murah dan mudah didapatkan, tidak menimbulkan pencemaran lingkungan serta dapat meningkatkan ketersediaan pakan untuk peternak. Penelitian ini bertujuan mempelajari siklus hidup BSF pada media limbah pasar serta mengetahui potensi Larva BSF mengurai limbah pasar.

\section{BAHAN DAN METODE}

\section{Waktu dan Tempat Penelitian}

Penelitian ini dilaksanakan kurang lebih selama delapan bulan, dikandang percobaan di Desa Jurit Kecamatan Pringgasela, Kabupaten Lombok Timur tempat pemeliharaan Larva BSF (Black Soldier Fly).

\section{Materi Penelitian}

Ternak Percobaan, Ternak percobaan yang digunakan dalam penelitian ini adalah Lalat BSF (Black Soldier Fly) betina yang berperan sebagai indukan, (di dapat dari maggot yang dipelihara sampai menjadi pupa dan menjadi lalat dewasa). Alat yang digunakan dalam penelitian ini meliputi jaring nilon, bak kayu, sarung tangan, timbangan digital, pisau cutter, wadah plastik, kertas label dan alat tulis. Bahan yang digunakan adalah limbah pasar yang diambil dari desa Jurit Kecamatan Pringgasela, Kabupaten Lombok Timur.

\section{Persiapan Media Limbah Organik}

Limbah Pasar yang diambil dari berbagai pasar diolah dengan 2 cara yaitu 1) media pertama: limbah pasar dipotong kecil-kecil atau dicacah, 2) media kedua: limbah pasar tidak dipotong atau dicacah. Setelah itu ditaruh dalam wadah media untuk diberikan ke larva BSF untuk menjadi bahan makanannya. Dimana limbah media pasar (buah dan sayuran) itu harus dicecer cara penaruhannya.

\section{HASIL DAN PEMBAHASAN}

Karakteristik Limbah Pasar Di Desa Jurit Sebagai Bahan Utama Media Penelitian

Penelitian ini memanfaatkan limbah pasar yang berada di desa Jurit kecamatan pringgasela, Limbah pasar ini menjadi masalah yang cukup serius pada pasar, karena menimbulkan bau yang sangat menyengat dan lingkungan pasar yang menjadi sangat kotor, karena limbah ini berserakan dimana-mana. Karakteristik limbah pasar yang digunakan dalam penelitian ini tertera pada Tabel 1 .

Tabel 1. Karakteristik Limbah pasar sebagai media penelitian

\begin{tabular}{ll}
\hline Limbah Pasar & Persentase \\
\hline Limbah buah-buahan & $45 \%$ \\
Limbah sayuran & $50 \%$ \\
Limbah rumah tangga & $5 \%$ \\
\hline
\end{tabular}




\section{Pengamatan Siklus Hidup Magot Pada Media Penelitian}

Maggot adalah organisme pada fase kedua dari siklus hidup lalat black soldier. Telur lalat black soldier menetas dan menjadi maggot. Maggot beranjak pada fase pupa yang kemudian berubah menjadi lalat dewasa. Klasifikasi maggot adalah sebagai berikut: Kingdom: Animalia; Phylum: Arthropoda; Class: Insecta; Order: Diptera; Family: Stratiomyidae; Subfamily : Hermetiinae; Genus: Hermetia; Species: H. Illucens. Sebelum bertelur, lalat betina akan mencari tempat yang sesuai dan aman untuk meletakkan telurnya, Seperti terlihat pada gambar 1 Lalat BSF yang sedang bertelur.

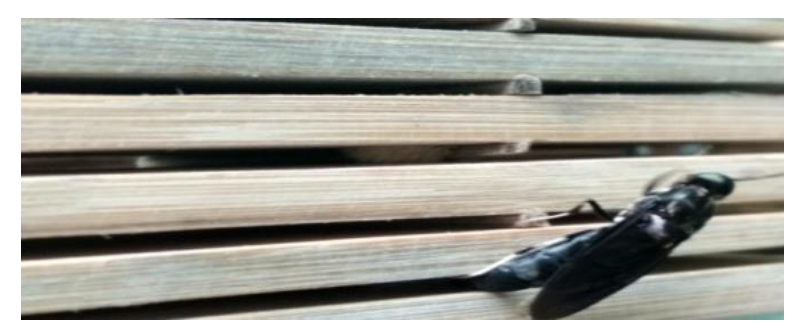

Gambar 1. Proses Bertelur Lalat Betina BSF

Lalat betina akan meletakkan telur pada hari kedua setelah kawin, Seperti terlihat pada Gambar.1 Lalat BSF akan bertelur ditempat yang sudah disiapkan, setelah bertelur lalat betina BSF akan mati, kemudian telur akan dipindahkan dalam media penetasan dari telur menetas menjadi larva, proses penetasan dari telur menjadi larva dalam waktu tiga sampai empat hari. Sesuai dengan penelitian Fahmi (2015), yang menyatakan bahwa telur lalat black soldier menetas setelah 3-6 hari. Menurut Fahmi et al. (2009) larva maggot berbentuk elips dan berwarna kuning muda serta hitam dibagian kepala. Fase larva yang masih berwarna putih kekuningan berlangsung kurang lebih 12 hari, pada fase ini larva akan sangat membutuhkan banyak makan, Larva magot bisa jadi mesin pengurai yang paling terbaik, magot ini bisa mengurai apa saja sampah organik, walapun dalam sampah itu ada banyak alkohol, asam dan lain-lainnya. Selanjutnya, larva mulai berubah menjadi coklat dan semakin gelap. Pada Fase prepupa terjadi sejak hari ke-19 dan fase pupa 100\% dicapai pada hari ke-24-26. Larva yang baru saja menetas umumnya berukuran $2 \mathrm{~mm}$ (Fahmi et al, 2009), kemudian berukuran $5 \mathrm{~mm}$ sebelum proses sheding kulit dimulai. Larva mulai tumbuh hingga $10 \mathrm{~mm}$ sebelum siap melepaskan kulit untuk berlanjut menjadi larva instar ketiga. Sebelum fase pre-pupa, larva instar ketiga tumbuh hingga $15 \mathrm{~mm}$ sampai $20 \mathrm{~mm}$.

Proses panen maggot dilakukan minimal setelah dua minggu masa Pemeliharaan maggot. Pada waktu 2 minggu telur lalat black soldier sudah menetas dan memasuki fase larva instar kedua yang tumbuh sekitar $10 \mathrm{~mm}$ sebelum melepaskan kulit menjadi larva instar ketiga. Larva instar ketiga tumbuh antara $15 \mathrm{~mm}$ dan $20 \mathrm{~mm}$ sebelum berada pada fase pre-pupa. Budidaya yang dilakukan dengan $100 \mathrm{~kg}$ bahan baku media kultur, dapat menghasilkan larva sebanyak $60-70 \mathrm{~kg}$. Perlu diingat daur hidup maggot sebelum menjadi lalat selama 37 hari. Jadi untuk pakan harus dilakukan sebelum Maggot berumur 37 haridari proses bertelurnya lalat. Proses pemanenan dilakukan dengan memisahkan maggot dari media tumbuhnya. Setelah terpisah dari media tumbuhnya, maggot siap diberikan untuk pakan ayam. Sebagian maggot dibiarkan hingga berubah menjadi lalat dewasa. Lalat dewasa akan digunakan sebagai indukan 
pada budidaya berikutnya. Hal ini bertujuan agar budidaya maggot ini dapat berkelanjutan serta tidak tergantung indukan lalat black soldier dari luar.

Larva Magot yang akan dijadikan sebagai pengganti tepung ikan minimalnya dipanen setelah 20 hari dari usia 0 bayi larva sampai 20 hari menjadi larva, karena hasil dari larva yang didapat lebih besar. Menurut MeltaRini dkk (2009) Pertumbuha ukuran maggot berdasarkan umur sebagai berikut, umur 2-4 hari maggot memiliki panjang tubuh 2-5 $\mathrm{mm}$ dan lebar 0,4-1 $\mathrm{mm}$, umur 6-9 hari memiliki ukuran panjang 5-10 mm dan lebar 1-2,5 mm, umur 10-13 hari memiliki ukuran panjang 10- $15 \mathrm{~mm}$ dan lebar 2-3 $\mathrm{mm}$, dan ukuran maksimal maggot dicapai setelah 20 hari yaitu panjang 20-25 mm dan lebar $5 \mathrm{~mm}$. Oleh sebab itu magot yang akan dijadikan sebagai pengganti tepung ikan dalam pembuatan bahan pakan sangat tepat dipanen pada saat berusia 20 hari.

\section{Potensi Lalat BSF Sebagai Agen Biokoversi Sampah Organik}

Biokonversi BSF ini merupakan cara mengolah sampah yang sangat sederhana dan tidak memerlukan biaya yang mahal. Penelitian ini menggunakan media Limbah pasar. Potensi penguraian limbah dihitung dalam persentase yang didapat dari total sampah yang diberikan dikurangi dengan sisa sampah dan maggot, kemudian dibagi total sampah dikali $100 \%$. Rata2 persentase limbah yang dapat didegradasi tertera pada Tabel 2.

Tabel 2. Rata-rata Persentase Limbah Organik yang didegradasi oleh Larva BSF

\begin{tabular}{clc}
\hline \multirow{2}{*}{ Pengujian } & \multicolumn{2}{c}{ Limbah Pasar } \\
\cline { 2 - 3 } & Dicacah & Tidah dicacah \\
\hline uji 1 & 85 & 75 \\
uji 2 & 90 & 65 \\
uji 3 & 85 & 60 \\
uji 4 & 75 & 70 \\
uji 5 & 85 & 75 \\
RATA2 & 84 & 69 \\
STDV & 4.90 & 5.83 \\
\hline
\end{tabular}

Berdasarkan Tabel 2. Menunjukkan bahwa larva /maggot mampu mengurai sampah hingga $84 \pm 4.90 \%$ jika sampah dihaluskan/dicacah dan $69 \pm 5.83 \%$ jika sampah tidak dicacah. Pencacahan ini memberikan kesempatan larva BSF mendapatkan makanan lebih merata sehingga persentase lebih tinggi dibandingkan dengan persentase jika tanpa pencacahan.

\section{Magot Sebagai pengganti Tepung Ikan}

Magot yang akan dijadikan sebgai pengganti tepung ikan dalam pembuatan bahan pakan ini dipanen pada saat berusia 20hari. Fresh Magot yang baru dipanen kemudian dicampur dengan bahan-bahan seperti dedak $5 \mathrm{~kg}$, jagung $5 \mathrm{~kg}$ (jagung yang dipakai disini yang sudah digiling) dan fresh magotnya $5 \mathrm{~kg}$, semua bahan dicampur jadi satu kemudian diaduk sampai merata semua bahan-bahannya, setelah tercampr dengan sempurna, semua bahan-bahan yang tadi dimasukkan kedalam mesin penggilingan sedikit demi sedikit. Dalam proses penggilingan jika bahannya terllu kering bisa ditambahkan sedikit air atau minyak goremg supaya 
memudahkan dalam mesin penggilingan pelet. Seperti terlihat pada Gambar 2, bahan-bahan yang dimasukkan kedalam mesin penggiling keluar dalam berbentuk pelet, cetakan pelet yang digunakan pada gambar 2 itu menggunakan cetakan pelet dengan besar lubang $6 \mathrm{~cm}$, bisa juga menggunakan cetakan pelet dengan lubang $3 \mathrm{~cm}$,tergantung dari yang diinginkan peternak.

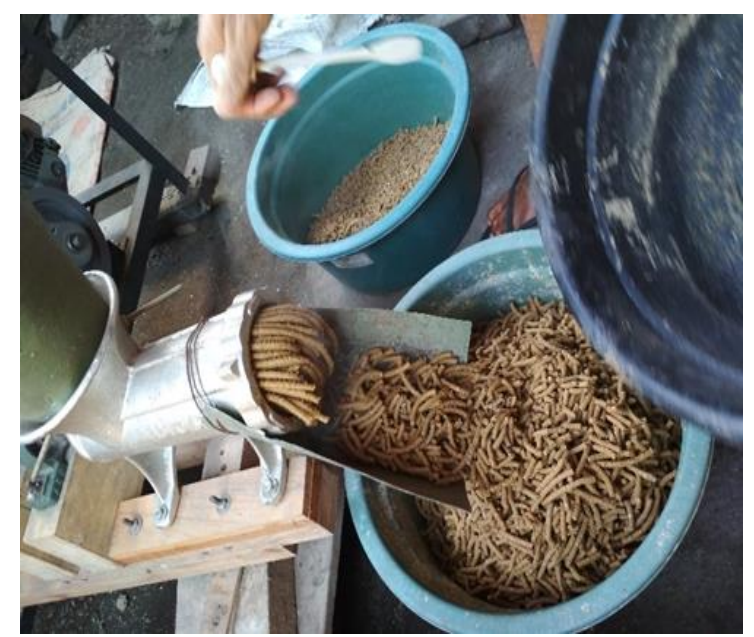

Gambar.2 Penggilingan Pelet Magot

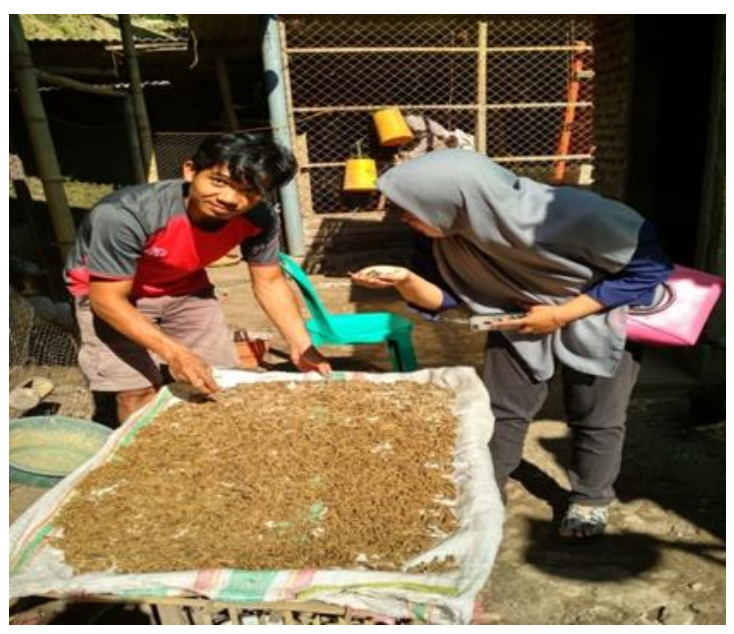

Gambar.3 Pengeringan Pelet

Pelet yang sudah jadi masih dalam keadaan basah, dan belum siap diberikan ke ternak, setelah proses penggilingan selesai pelet dijemur dibawah sinar matahri terlebih dahulu, bisa juga dimasukkan dalam mesin pengering tapi dalam penelitian ini kami masih menggunakan cahaya matahari langsung, dalam proses penjemuran pelet sepearti terlihat pada Gambar.3 berlangsug dua hari. Tujuan dari pngeringan ini juga untuk membuat pelet bertahan lama.

Peternak yang ada di desa jurit sudah tidak perlu lagi membeli tepung ikan untuk campuran pembuatan Pakan karena magot bisa sebagai pengganti tepung ikan dalam pembuataan pelet dan bahan pakan yang lainnya. Menurut Fahmi dkk, (2007) Maggot mengandung protein sekitar 32,31\%-60,2\% dan lemak yang cukup tinggi sekitar 9,45\%-13,3\% tergantung umur dan kualitas substrat, Sehingga Pemanfaatannya sebagai bahan pakan sangat potensial. Dengan adanyan budidaya magot ini para peternak yang berada di desa jurit sudah sangat terbantu, peternak tidak perlu lagi untuk mencari tepung ikan yang memang sangat langka di indonesia terutama di lombok timr. Selain tidak bersaing dengan kebutuhan manusia, magot ini juga sangat potensial untuk pengelolaan sampah organik sehingga masyarakat sudah tidak perlu membuang sampah ke kali, dan limbah pasar seperti buah-buahan dan sayur mayur dapat dimanfaatkan dengan baik, permasalahan sampah organikpun sedikit demi sedikit bisa teratasi dengan adanya penelitian ini. Para pedagang atau ibu rumah tangga tidak perlu membuang sampah ke sungai lagi, Cukup ditaruh dengan baik dalam plastik peternak pembudidayan Magot akan datang mengambil dengan sendirinya. Dengan adanya Penelian ini baik masyarakat atau peternak mampu mengolah sampah dengan baik dan benar.

\section{KESIMPULAN}

Berdasarkan hasil dan pembahasan dapat disimpulkan bahwa proses penetasan dari telur menjadi larva dalam waktu tiga sampai empat hari. Fase larva yang masih berwarna putih 
kekuningan berlangsung kurang lebih 12 hari dan fase ini larva sangat membutuhkan banyak makan. Pada Fase prepupa terjadi sejak hari ke-19 dan fase pupa 100\% dicapai pada hari ke24-26. Magot memiliki kemampuan mendegradasi limbah pasar yang dicacah hingga $84 \pm 4.90$ $\%$ dan pada limbah yang tidak dicacah sekitar $69 \pm 5.83 \%$.

Masyrakat atau para peternak sudah tidak perlu menggunakan tepung ikan dalam pembuatan pelet dan pakan lainnya, melainkan dapat menggunakan magot sebagai pengganti tepung ikan.

\section{DAFTAR PUSTAKA}

Banks IJ, Gibson WT, Cameron MM. 2014. Growth rates of Black Soldier Fly larvae on fresh human faeces and their implication for improving sanitation. Trop Med Int Heal. 19:14-22.

Beski SSM, Swick RA, Iji PA. 2015. Specialised protein products in broiler chicken nutrition: A review. Anim Nutr. 1:47-53.

Čičková H, Newton GL, Lacy RC, Kozánek M. 2015. The use of fly larvae for organic waste treatment. Waste Manag. 35:68-80.

Diener S, Studt Solano NM, Roa Gutiérrez F, Zurbrügg C, Tockner K. 2011. Biological treatment of municipal organic waste using Black Soldier Fly larvae. Waste Biomass Valorization. 2:357-363

Dong SZ, Chen YF, Huang YH, Feng DY. 2009. Research on feed characteristics of Bacillus natto. Chinese J Anim Nutr. 21:371-378.

Fahmi, M. R. (2015). Optimalisasi proses biokonversi dengan menggunakan mini-larva Hermetia illucens untuk memenuhi kebutuhan pakan ikan. In Prosiding Seminar Nasional Masyarakat Biodiversitas Indonesia (Vol. 1, pp. 139-144). https://doi.org/10.13057/psnmbi/m010124

Fahmi, M. R., Hem, S., \& Subamia, I. W. (2009). Potensi maggot untuk peningkatan pertumbuhan dan status kesehatan ikan. Jurnal Riset Akuakultur, 4(2), 221-232.

Fahmi, M. R., 2015. Optimalisasi proses biokonversi dengan menggunakan mini-larva Hermetia illucens untuk memenuhi kebutuhan pakan ikan. Pros sem nas masy biodiv indon 1(1), pp. 139-144.

Fahmi, 2010. Perkembangan dan kandungan nutrisi larva Hermetia illucens (Linnaeus) (Diptera: Stratiomyidae) pada bungkil kelapa sawit. J Entomol Indon 7(1), pp. 28-41.

Gabler, F. 2014. Using black soldier fly for waste recycling and effective Salmonella spp. reduction. Theses. Swedish University of Agricultural Sciences, Swedish.

Gobbi, P., A. Martínez-Sánchez, dan S. Rojo, 2013. The effects of larval diet on adult lifehistory traits of the black soldier fly, Hermetia illucens (Diptera: Stratiomyidae). Eur J Entomol 110 (3), pp. 461-468.

Harahap, S. (2013). Pencemaran perairan akibat kadar amoniak yang tinggi akibat limbah cair industri tempe. Jurnal Akuatika, 4(2), 183-194.

Hadisuwito, S., 2007. Membuat Pupuk Kompos Cair. PT. Agromedia Pustaka, Jakarta.

Hartoyo, \& Sukardi, P. (2007). Alternatif Pakan Ternak Ikan. Purwokerto: Universitas Jenderal Soedirman. 
Holmes, L.A., Vanlaerhoven, S.L., Tomberlin, J.K. 2012. Relative Humidity Effects on the Life History of Hermetia illucens (Diptera: Stratiomyidae). Environmental Entomology, 41(4): 971-978.

Larde, G. 1990. Recycling of Cofee Pulp by Hermetia illucens (Diptera: Stratiomyidae)larvae. Biological wastes. 33: 307-310.

Leclercq, M. (1997): A propos de Hermetia illucens (Linnaeus, 1758) "soldier fly" (diptera stratiomyidae: hermetiinae). Bulletin et annales de la societe royale belge d'entemologie. 133: 275-282.

Li, Q., Zheng, L., Qiu, N., Cai, H., Tomberlin, J,K. \& Yu, Z. 2011. Bioconversion of manure by black soldier fly (diptera: stratiomyidae) for biodiesel and sugar production. Waste management.31:13161320.

Makkar HPS, Tran G, Heuze V, Ankreas P. 2014. State of the art on use of insects as animal feed. Anim Feed Sci Technol. 197:1-33.

Manurung R., Supriatna A., Esyanti R. E. \& Putra R. E. 2016. Bioconversion of Rice Straw by Black Soldier Fly Larvae (Hermetia illucnes): Optimal Feed Rate For Biomass Production. Journal of Entomology and Zoology Studies; 4 (1).

Myers HM, Tomberlin JK, Lambert BD, Kattes D. 2008. Development of Black Soldier Fly (Diptera: Stratiomyidae) larvae fed dairy manure. Environ Entomol. 37:11-15.

Newton, G. L., Sheppard, D. C., Watson, D. W., Burtle, G. \& Dove, R. 2005. Using the Black Soldier Fly, Hermetia illucens, as a Value Added Tool for Management of Swine. Manure. Animal and Poultry Waste Management Center, North Carolina State University, Raleigh, NC. pp. 17.

Oliver, P. A. 2004. The Bioconversion of Putrescent wastes. Engineering separation recycling (ESR). Washington, Lousiana.

Rachmawati, Buchori D, Hidayat P, Hem S, Fahmi MR. 2010. Perkembangan dan kandungan nutrisi larva Hermetia illucens (Linnaeus) (Diptera: Startiomyidae) pada bungkil kelapa sawit. J Entomol Indones. 7:2841.

Sheppard DC, Tomberlin JK, Joyce JA, Kiser BC, Sumner SM. 2002. Rearing methods for the Black Soldier Fly (Diptera: Stratiomyidae). J Med Entomol. 39:695698.

Supriyatna A. \& Ukit. 2016. Screening and Isolation of Cellulolytic Bacteria from Gut of Black Soldier Flys Larva (Hermetiaillucens) Feeding with Rice Straw. Journal of Biology \& Biology Education. Biosaintifika. 8(3): 314-320.

Tomberlin JK, Adler PH, Myers HM. 2009. Development of the Black Soldier Fly (Diptera: Stratiomyidae) in relation to temperature. Enviromental Entomol. 38:930-934.

Tomberlin JK, Sheppard DC, Joyce JA. 2002. Selected lifehistory traits of Black Soldier Flies (Diptera: Stratiomyidae) reared on three artificial diets. Ann Entomol Soc Am. 95:379-386.

Tomberlin JK, Sheppard DC. 2002. Factors influencing mating and oviposition of Black Soldier Flies (Diptera: Stratiomyidae) in a colony. J Entolomogy Sci. 37:345-352.

Yu G, Cheng P, Chen Y, Li Y, Yang Z, Chen Y, Tomberlin JK. 2011. Inoculating poultry manure with companion bacteria influences growth and development of Black Soldier Fly (Diptera: Stratiomyidae) larvae. Environ Entomol. 40:30-35 23. 
Zakova M, Barkovcova M. 2013. Comparison of field and lab application of Hermetia illucens larvae. Mendelnet. 2013:798-801.

Zheng, L., Li Q., Zhang, J. \& Yu, Z. 2011. Doeble the Biodiesel Yield: Rearing Black Soldier Fly Larvae, Hermetia illucens, on Solid Residual Fraction of Resteurant Waste After Grease Extraction for Biodiesel Production. Renewable Energy. 1-5. 